\title{
Guillain-Barré syndrome: Clinical profile and Consensus to revise Hughes grade 5
}

\author{
Sandhya Manorenj ${ }^{1}$, Snehalatha Inturi ${ }^{2}$, B .Jyotsna ${ }^{3}$, Devender Arelli ${ }^{4}$, O Balarami Reddy ${ }^{5}$, Narayana Pancheti ${ }^{6}$
}

\section{Sandhya Manorenj', Snehalatha Inturi' ${ }^{2}$, B Jyotsna ${ }^{3}$, Devender Arelli ${ }^{4}$, O Balarami Reddy ${ }^{5}$, Narayana Pancheti ${ }^{6}$}

${ }^{1-6}$ Department of Neurology, Employees State Insurance Corporations Superspeciality Hospital, Sanath Nagar HYderabad, INDIA.

\section{Correspondence}

Dr Sandhya Manorenj,

Department of Neurology, Employees State Insurance Corporations Superspeciality Hospital ,Sanath Nagar HYderabad.

Ph.no:9533495676

Email:drsandhyamanorenj@gmail.com

\section{History}

- Submission Date: 16-05-2016;

- Review completed: 23-08-2016;

- Accepted Date: 07-10-2016.

DOI : 10.5530/ijmedph.2016.4.10

Article Available online

http://www.ijmedph.org/v6/i4

\section{Copyright}

(C) 2016 Phcog.Net. This is an openaccess article distributed under the terms of the Creative Commons Attribution 4.0 International license.

\begin{abstract}
Background: Guillain-Barré Syndrome (GBS) is an acute, immune-mediated polyradiculoneuropathy and an important cause of acute flaccid paralysis (AFP) worldwide. Respiratory insufficiency requiring ventilator occurs in $30 \%$ of patients that prolong the hospital stay, leading to morbidity and mortality. There had been relatively few studies of Guillain-Barre syndrome in adults from South India. Aim: To evaluate clinical profile, epidemiological, laboratory, and electro diagnostic features of patients with GBS in adults. Settings and design: A prospective study was conducted over a period of 4 years at ESIC Superspeciality Hospital, Hyderabad. Materials and methods: Total 36 patients were identified and data was collected. We studied the epidemiological, clinical, electrophysiological features and their outcome. We subdivided Hughes grade 5 into $5 A$ and $5 B$ based on the requirement of ventilator. Statistical Analysis: Data obtained in the study were subjected to statistical analysis with Statistical Package for Social Sciences (SPSS) version 18. Bivariate analysis was done using chi-square test. Results: Of 36 GBS patients, 21(58.3\%) were males; the mean age was 35 years. Antecedent infection was found in 23(63.8\%). Majority 12 (33\%) were in Hughes grade 4, 10 (27.7\%) were in Hughes grade 5A. 97.2\% had limb weakness. A significant association was found between low Medical research sum score (MRC) and respiratory failure. Most predominant neurophysiological variant was acute inflammatory demyelinating polyradiculoneuropathy (AIDP) 12 (33.3\%). Duration of illness was less than 1 week in $19(52.7 \%)$ of cases. Asymmetry was observed in $5(13.8 \%)$ and recurrence of Guillain-Barre Syndrome seen in $2(5.5 \%)$ cases. Complete recovery was noted at 6 months in 34 (94.4\%) cases. Conclusion: Early diagnosis of respiratory failure and prompt intervention improves patient outcome. Further large sample studies are required to assess respiratory failure and subdivision of Hughes grade 5.
\end{abstract}

Key words: GBS, Hughes grade, Clinical profile.

\section{INTRODUCTION}

GBS is the major cause of acute neuromuscular paralysis with an annual incidence of 0.6-2.4 per 100,000 worldwide. ${ }^{1,2}$ There are no incidence studies of GBS in Indian population. ${ }^{3}$ GBS incidence increased by $20 \%$ for every 10 -year increase in age; the risk of GBS was higher for males than females. ${ }^{4}$

GBS can cause life-threatening complications if the respiratory muscles are affected or if autonomic nervous system is involved. The weakness reaches its nadir in 2-4 weeks. About 5\% of the patients die and more patients are left with a disabling motor deficit and/ or fatigue. About $30 \%$ of patients have respiratory failure due to progressive weakness of respiratory muscles requiring ventilator. ${ }^{5}$ Aspiration pneumonia and atelectasis are common consequences of bulbar muscle weakness. Several factors at admission and during the ICU stay are known to predict a need for invasive mechanical ventilation. These include rapidly progressive motor weakness, involving the peripheral limbs and the axial muscles, ineffective cough, bulbar muscle weakness, and a rapid decrease in vital capacity. Recognition of early respiratory fail- ure in-patients with Hughes grade 4 can prevent the requirement of mechanical ventilator.

\section{MATERIALS AND METHODS}

A prospective study was conducted from January 2012 to January 2016 among the patients admitted in department of Neurology, Hyderabad in South India, where 36 consecutive GBS patients, underwent detailed clinical and electrophysiological assessment. Institutional Ethics Committee approved the study protocol and written informed consent was taken from all relatives of participant.

Information regarding the relevant variables in the study was collected with the help of structured proforma comprising age, sex, antecedent infections, duration of illness, seasonal trend, clinical variant, recurrence, asymmetry, CSF analysis, electrophysiological variant, Hughes disability score, treatment opted and outcome assessed at 1,3,6 and 12 months. The diagnosis of GBS was made using the Asbury and Cornblath criteria. ${ }^{6}$ Medical Research Council (MRC) sum score was used for valuing the muscle strength from 0 to 5 in proxi-

Cite this article : Manorenj S, Inturi S, Jyotsna B, Arelli D, Reddy OB, Pancheti N. Guillain-Barré syndrome: Clinical profile and Consensus to revise Hughes grade 5. Int J Med. Public Health. 2016;6(4):193-9. 
mal and distal muscles in upper and lower limbs bilaterally; score ranged from 40 (normal) to 0 (quadriplegic) and by Hughes et al. disability score for GBS. ${ }^{7,8}$ We further subdivided Hughes grade 5 to $5 \mathrm{~A}$ and $5 \mathrm{~B}$ based on requirement of ventilator. (Table 1). Classification of patients as axonal or demyelinating subtype was based on electro diagnostic criteria of Hadden et al. ${ }^{9}$

Data obtained in the study were subjected to statistical analysis with Statistical Package for Social Sciences (SPSS) version 18. Categorical variables were summarized as counts (percentage) and continuous variables as means or medians (interquartile ranges (IQR)). Bivariate analysis was done using chi-square test to compare between respiratory failure group and non-respiratory group, demyelinating and axonal group. A twotailed probability value $<0.05$ was considered significant.

\section{Definition of Important Study Variables Case of GBS}

1) Acute onset of bilateral and relatively symmetric flaccid weakness/ paralysis of the limbs with or without involvement of respiratory or cranial nerve-innervated muscles.

2) Decreased or absent deep tendon reflexes at least in affected limbs, monophasic illness pattern, with weakness nadir reached between 12 hours and 28 days, followed by clinical plateau and subsequent improvement, or death.

3) Electrophysiological findings consistent with GBS.

4) Presence of albuminocytological dissociation (elevation of cerebrospinal fluid (CSF) protein level above laboratory normal value, and CSF total white cell count $<50$ cells $/ \mathrm{mm}$.

5) Absence of an alternative diagnosis for weakness.

\section{Recurrence of GBS}

A recurrence was defined as two or more episodes that fulfilled the diagnostic criteria for GBS, with a minimum time interval between each episode of 2 months (when fully recovered in between) or 4 months (when only partially recovered).

\section{Asymmetry}

Asymmetry in motor deficit demonstrated either clinically or electro physiologically.

\section{RESULTS}

\section{Demographic characteristics}

During the study period 36 GBS patients were identified. The age of incidence ranged from 19 years to 68 years having a mean age of 35 years. The median age of GBS patients was 34 years (interquartile range 23.5); $61.1 \%$ of patients were aged $<40$ years. $21(58.3 \%)$ of GBS patients were males. The male to female ratio was 1.4: 1 (Figure 1).
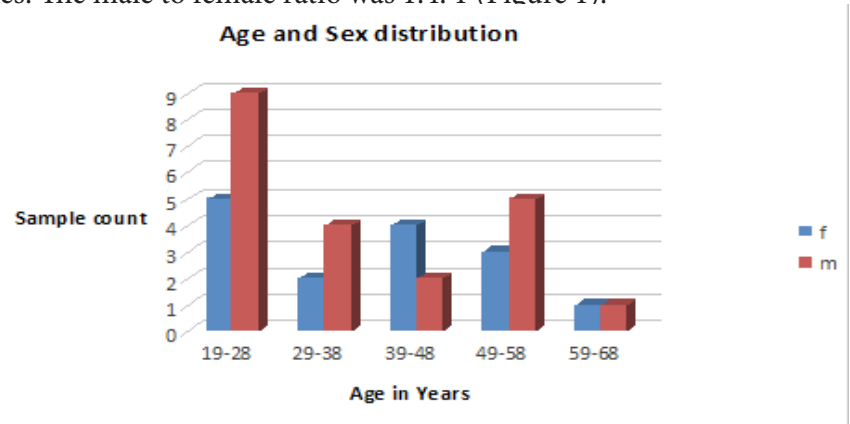

\section{Antecedent infections}

Antecedent infection was found in $23(63.8 \%)$ cases in the preceding two weeks, among which 12 (33\%) had respiratory infection, 8 (22\%) had gastrointestinal illness and non-specific febrile illness in $3(8.3 \%)$ cases. Seasonal occurrence predominantly in rainy season (June-September) was noted in 14 (38.8\%) cases followed by winter (December-February) in $11(30.5 \%)$ (Figure 2).

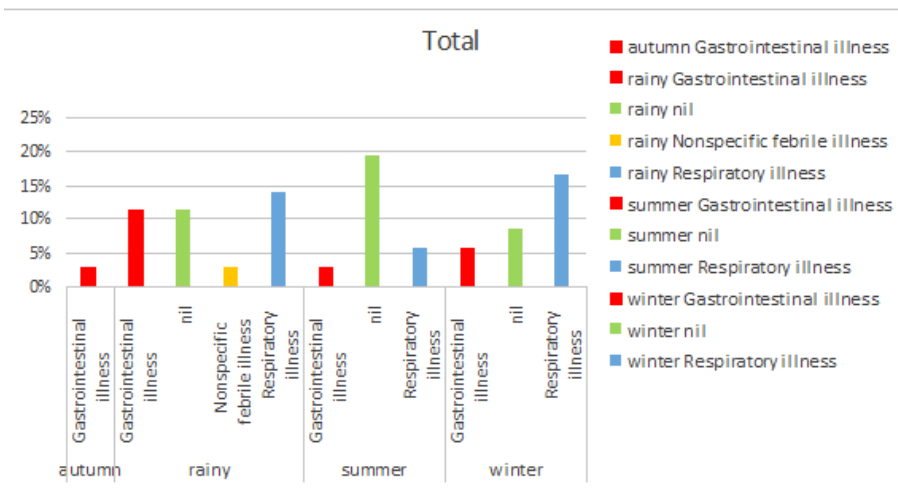

\section{Clinical characteristics}

Out of the total, $19(52.7 \%)$ patients presented with in one week of onset of illness, $11(30.5 \%)$ came with in 2 weeks, 3 (8.3\%) cases each in 3 weeks and 4 weeks of illness respectively. Symmetrical weakness was observed in 31 (86.1\%) and asymmetry in 5 (13.8\%). Motor weakness in $35(97.2 \%)$ was predominant, sensory symptoms in 29 (80.5\%), facial nerve involvement in 22 (61\%), autonomic disturbance in $13(36.1 \%)$ and bulbar palsy in $11(30.5 \%)$ cases. Quadriplegia/quadriparesis was the most common clinical variant $32(88.8 \%)$, paraplegia in $2(5.5 \%)$, pure sensory variant in $1(2.7 \%)$, Miller Fischer syndrome (MFS) in $1(2.7 \%)$ and isolated bulbar palsy in $1(2.7 \%)$ case. (Figure 3$)$. Early respiratory failure (Hughes grade $5 \mathrm{~A}$ ) was seen in 10 (27.7\%). It is found that patients who had respiratory failure $6(60 \%)$ had low MRC sum score (0-10) indicating severity of illness. There was statistically significant ( $\mathrm{P}$ value- 0.0035$)$ relation between low MRC sum score $(0-10)$ and respiratory failure on comparison with controls (non respiratory group). (Table 2)

Clinical features of GBS - Comparing with Electrodiagnostic feature

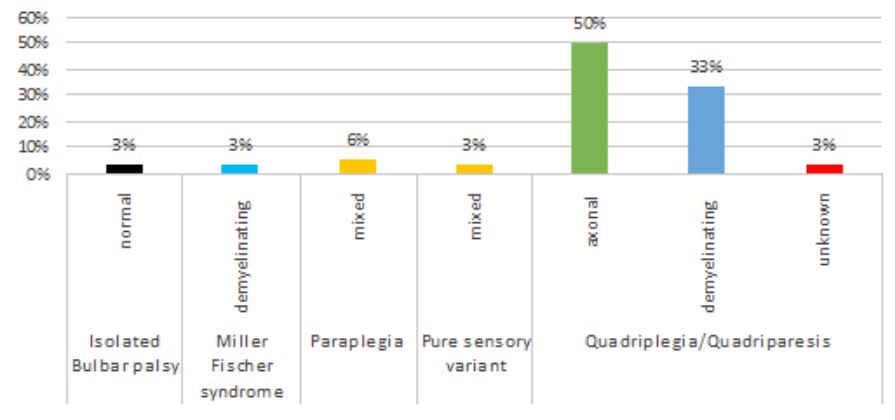

Most of the cases were in Hughes disability scale of 3 in 13(36\%), Hughes 4 in $11(30.5 \%)$, Hughes 5A in 10 (27.7\%) and Hughes grade 2 in 2(5.5\%) cases respectively. MRS sum score maximum was 40 and lowest was 0 in our study sample. Most of the patients 14 (38.8\%) were in MRC sum score range of 20-30. 30 (83.3\%) patients were in progressive phase, $3(8.3 \%)$ in plateau phase and $3(8.3 \%)$ in recovery phase. Recurrence 
Table 1: Hughes grade with subdivision of Grade V

\begin{tabular}{|c|c|}
\hline Grade 0 & Normal functional state \\
\hline Grade 1 & Able to run with minor signs and symptoms \\
\hline Grade 2 & Able to walk 5 metre independently \\
\hline Grade 3 & Able to walk with aid 5 metre \\
\hline Grade 4 & Bed or chair bound \\
\hline $\begin{array}{r}\text { Grade } 5 \\
\text { A }\end{array}$ & $\begin{array}{c}\text { With respiratory Failure } \\
\text { With early respiratory failure ,no requirement of } \\
\text { ventilator(Absence of ventilator) }\end{array}$ \\
\hline B & Respiratory failure requiring Mechanical ventilation \\
\hline Grade 6 & Death \\
\hline
\end{tabular}

Table 2: Baseline characteristics among respiratory and non respiratory failure group of GBS

\begin{tabular}{|c|c|c|c|}
\hline VARIABLE & RESPIRATORY(VA\&VB) $(n=10)$ & $\begin{array}{l}\text { NON RESPIRATORY } \\
(n=26)\end{array}$ & P VALUE \\
\hline \multicolumn{4}{|l|}{ AGE } \\
\hline$<40$ & $4(40 \%)$ & $18(69.2 \%)$ & 0.21 \\
\hline$>40$ & $6(60 \%)$ & $8(30.7 \%)$ & \\
\hline \multicolumn{4}{|l|}{ SEX } \\
\hline MALE & $5(50 \%)$ & $16(61.5 \%)$ & 0.80 \\
\hline FEMALE & $5(50 \%)$ & $10(38.46 \%)$ & \\
\hline \multicolumn{4}{|l|}{ MRC GRADING } \\
\hline $0-10$ & $6(60 \%)$ & 0 & 0.000083 \\
\hline $11-30$ & $3(30 \%)$ & $17(65.3 \%)$ & \\
\hline $31-40$ & $1(10 \%)$ & $9(34.6 \%)$ & \\
\hline CSF Study & $\mathrm{N}=10$ & $\mathrm{~N}=23$ & \\
\hline \multicolumn{4}{|l|}{ Done (33) } \\
\hline PLEOCYTOSIS & $8(80.00 \%)$ & $18(69.00 \%)$ & 0.91 \\
\hline \multicolumn{4}{|l|}{ TIC STUDY } \\
\hline AIDP & $5(55.5 \%)$ & $7(26.9 \%)$ & 0.45 \\
\hline AMAN & $2(22.2 \%)$ & $7(26.9 \%)$ & \\
\hline AMSAN & $1(11.1 \%)$ & $8(30.7 \%)$ & \\
\hline MIXED & $1(11.1 \%)$ & $3(15.3 \%)$ & \\
\hline
\end{tabular}

Table 3 : Neurological deficit and Guillain-Barre disability score

\begin{tabular}{|c|c|}
\hline Motor deficits & Number (Percentage) \\
\hline Mild $\quad$ (MRC 31-40) & $10(27.7 \%)$ \\
\hline Moderate (MRC 11-30) & $20(55.5 \%)$ \\
\hline Severe $\quad($ MRC $0-10)$ & $6(16.6 \%)$ \\
\hline \multicolumn{2}{|l|}{ Other clinical features } \\
\hline Sensory deficits & $29(80.5 \%)$ \\
\hline Facial palsy & $22(61.1 \%)$ \\
\hline Bulbar weakness & $11(30.5 \%)$ \\
\hline Autonomic disturbances & $13(36.1 \%)$ \\
\hline Respiratory distress & $10(27.7 \%)$ \\
\hline \multicolumn{2}{|l|}{ GBS disability score } \\
\hline Mild symptoms or sign $\quad$ (grade 1) & 0 \\
\hline Walk without support （grade 2) & $2(5.5 \%)$ \\
\hline Walk with support $\quad$ (grade 3 ) & $13(36 \%)$ \\
\hline Bedridden or wheel chair bound $\quad$ (grade 4$)$ & $11(30.5 \%)$ \\
\hline \multicolumn{2}{|l|}{ Early respiratory failure } \\
\hline ( Not requiring ventilator) (grade $5 \mathrm{~A})$ & $10(27.7 \%)$ \\
\hline Respiratory failure requiring ventilator (grade 5B) & 0 \\
\hline (grade 6) & 0 \\
\hline
\end{tabular}


Table 4: Comparison between demyelinating and axonal variant of GBS

\begin{tabular}{|c|c|c|c|}
\hline VARIABLE & $\begin{array}{l}\text { DEMYELINATING } \\
\qquad(n=12)\end{array}$ & $\begin{array}{c}\text { AXONAL } \\
(n=18)(\text { AMSAN+AMAN })\end{array}$ & P VALUE \\
\hline MEAN AGE & 46 & 35 & $\mathrm{~V}$ \\
\hline $\begin{array}{c}\text { SEX RATIO(M:F) } \\
\text { Male } \\
\text { Female }\end{array}$ & $\begin{array}{l}0.7: 1 \\
5 \\
7\end{array}$ & $\begin{array}{c}2.6: 1 \\
13 \\
5\end{array}$ & 0.09 \\
\hline $\begin{array}{c}\text { ANTECEDENT INFECTION } \\
\text { RESPIRATORY ILLNESS } \\
\text { GIT } \\
\text { NONSPECIFIC } \\
\text { NIL }\end{array}$ & $\begin{array}{c}4(33.3 \%) \\
1(8.3 \%) \\
0 \\
7(58.3 \%)\end{array}$ & $\begin{array}{l}4(22.2 \%) \\
7(38.8 \%) \\
2(11.1 \%) \\
5(27.7 \%)\end{array}$ & 0.11 \\
\hline $\begin{array}{l}\text { DURATION OF ILLNESS } \\
\quad<1 \text { week } \\
\quad<2 \text { weeks } \\
<3 \text { weeks } \\
<4 \text { weeks }\end{array}$ & $\begin{array}{c}7(58.3 \%) \\
5(41.6 \%) \\
0 \\
0\end{array}$ & $\begin{array}{l}7(38.8 \%) \\
6(33.3 \%) \\
3(16.6 \%) \\
2(11.1 \%)\end{array}$ & $\begin{array}{c}0.29 \\
0.64 \\
0.13 \\
0.23 \\
0\end{array}$ \\
\hline $\begin{array}{c}\text { Mild MRC(31-40) } \\
\text { Moderate MRC(11-30) } \\
\text { Severe MRC(0-10) }\end{array}$ & $\begin{array}{c}2(16.6 \%) \\
7(58.3 \%) \\
3(25 \%)\end{array}$ & $\begin{array}{c}3(16.6 \%) \\
11(61.1 \%) \\
4(22.2 \%)\end{array}$ & $\begin{array}{c}1 \\
0.87 \\
0.86\end{array}$ \\
\hline $\begin{array}{c}\text { SENSORY DEFICITS } \\
\text { FACIAL PALSY } \\
\text { AUTONOMIC DYSFUNC- } \\
\text { TION }\end{array}$ & $\begin{array}{l}12(100.00 \%) \\
9(75.00 \%) \\
6(50.00 \%) \\
5(41.60 \%)\end{array}$ & $\begin{array}{c}10(55.50 \%) \\
11(61.10 \%) \\
6(33.30 \%) \\
3(16.60 \%)\end{array}$ & $\begin{array}{c}0.007 \\
0.42 \\
0.36 \\
0.12\end{array}$ \\
\hline RESPIRATORY FAILURE & & & \\
\hline $\begin{array}{c}\text { HUGHES GRADING } \\
\text { Grade } 1 \\
\text { Grade } 2 \\
\text { Grade } 3 \\
\text { Grade } 4 \\
\text { 5A(without ventilator) } \\
\text { 5B(with ventilator) } \\
\text { Grade } 6\end{array}$ & $\begin{array}{c}0 \\
0 \\
5(41.6 \%) \\
1(8.3 \%) \\
6(50 \%) \\
0 \\
0\end{array}$ & $\begin{array}{c}0 \\
1(5.5 \%) \\
6(33.5 \%) \\
8(44.4 \%) \\
3(16.6 \%) \\
0 \\
0\end{array}$ & 0.08 \\
\hline $\begin{array}{l}\text { CSF ALBUMINO CYTO- } \\
\text { LOGICAL DISSOCIATION }\end{array}$ & $11(91.6 \%)$ & $11(61.1 \%)$ & 0.06 \\
\hline CSF ALBUMIN $>100$ & $4(36.3 \%)$ & $3(27.2 \%)$ & \\
\hline CSF ALBUMIN $<100$ & $7(63 \%)$ & $8(72.7 \%)$ & 0.64 \\
\hline
\end{tabular}

was seen in 2 (5.5\%) cases. Table 3 showing the neurological deficit and Guillain-barre disability score. [Table 3]

Cerebrospinal fluid (CSF) analysis was done in 33 (91.6\%) cases, out of which albuminocytological dissociation was seen in 27 (81.8\%), 23 (69\%) had CSF protein of $>50 \mathrm{mg} / \mathrm{dl}$ and $6(18 \%)$ had protein value of $>100$ $\mathrm{mg} / \mathrm{dl}$. Mean CSF protein level was $(\mathrm{n}=33) 80.27 \mathrm{mg} / \mathrm{dl}$. CSF pleocytosis (> 10 cells) was seen in $2(6.06 \%)$ cases who had recurrence GBS. Antiganglioside antibody testing was done in 1 patient $(2.7 \%)$ who had recurrent isolated bulbar palsy with normal nerve conduction study, with total MRC sum score of 40, found to have anti GM3 and anti GT1b antibody against IgG and Ig M subclass.

\section{Electro diagnostic characteristics}

Nerve conduction study was conducted in 35 cases (97.2\%). AIDP was seen in $12(34.2 \%)$, acute motor axonal neuropathy (AMAN) in $9(25.7 \%)$, acute motor sensory axonal neuropathy (AMSAN) in $9(25.7 \%)$ mixed in $4(11.1 \%)$ cases and normal in $1(2.8 \%)$ case. Overall axonal type (AMAN+ AMSAN) of GBS (51.4\%) was more than the demyelinating type $(34.2 \%)$. Females 7 (58.3\%) were predominantly affected in demyelinating form of GBS, whereas males 13 (72.2\%) dominated in axonal form of GBS. Mean age was 46 in demyelinating group and 35 in axonal forms of GBS. There was a significant association between sensory deficits and type of neuropathy ( $p$ value 0.0007 ). Respiratory failure was noted in 5 (41.6\%) cases of demyelinating form (AIDP) of GBS, only $3(16.6 \%)$ developed respiratory failure in axonal form. (Table 4 )

\section{Treatment and Outcome}

Out of 36 patients, 32 (88.8\%) received Intravenous Immunoglobulin (IVIG). 1 (2.7\%) received plasmapharesis, and 3(8.3\%) did not receive any treatment either due to minimal weakness or in recovery phase. 3 cases $(8.3 \%)$ required repeat IV IG administrations. Outcome was assessed at discharge, and at 1, 3, 6, and 12 months. 32 (88.8\%)cases were able to walk with or without support at 3 months, and complete recovery at 6 months 33(91.6\%), 2 cases (5.5\%) recovered at 12 months and 1 case (2.7\%) was bed bound. Complete recovery at 12 months was 35 (97.2\%). 
Table 5: Showing comparison of previous clinical studies conducted in India and present study

\begin{tabular}{|c|c|c|c|c|c|c|c|c|}
\hline & Characteristics & $\begin{array}{c}\text { Amita } \\
\text { Bhargav et al } \\
{[10]}\end{array}$ & $\begin{array}{c}\text { Dhadke SV } \\
\text { et al } \\
{[11]}\end{array}$ & $\begin{array}{c}\text { Sudulugunta } \\
\text { SR et al } \\
{[12]}\end{array}$ & $\begin{array}{c}\text { Maneesh } \\
\text { Kumar et al } \\
{[13]}\end{array}$ & $\begin{array}{c}\text { Ujjal KR } \\
\text { Sarkar et al } \\
{[14]}\end{array}$ & $\begin{array}{c}\text { Kalita J et al } \\
\text { [15] }\end{array}$ & Our study \\
\hline \multirow[t]{7}{*}{1} & Epidemiology & & & & & & & \\
\hline & (a)Study region & $\begin{array}{l}\text { Jodhpur } \\
\text { North India }\end{array}$ & $\begin{array}{c}\text { Solapur } \\
\text { Central India }\end{array}$ & $\begin{array}{l}\text { Bangalore } \\
\text { South India }\end{array}$ & $\begin{array}{c}\text { Manipal } \\
\text { (south India) }\end{array}$ & $\begin{array}{c}\text { Kolkata } \\
\text { (Eastern } \\
\text { India) }\end{array}$ & $\begin{array}{l}\text { Lucknow (North } \\
\text { India) }\end{array}$ & $\begin{array}{l}\text { Hyderabad } \\
\text { (South India) }\end{array}$ \\
\hline & (b)Type of study & Prospective & Prospective & Retrospective & Cross sectional & $\begin{array}{l}\text { Retrospec- } \\
\text { tive study }\end{array}$ & Cross sectional & Prospective \\
\hline & (c)Sample of study (n) & $\begin{array}{c}61 \\
\text { (both) }\end{array}$ & $\begin{array}{c}40 \\
\text { (both) }\end{array}$ & $\begin{array}{l}1166 \\
\text { (Both) }\end{array}$ & $\begin{array}{c}20 \\
\text { (children) }\end{array}$ & $\begin{array}{c}139 \\
\text { (children) }\end{array}$ & 51 & $\begin{array}{c}36 \\
\text { (adults) }\end{array}$ \\
\hline & (d)Study period (months) & 26 & 20 & 132 & 18 & 120 & & 48 \\
\hline & (e)Age range(yrs) & $8-78$ & $13-40$ & $0-85 y r s$ & $1.3-17 \mathrm{yrs}$ & $2-12 \mathrm{yrs}$ & & $19-68$ \\
\hline & (f)Male: female & $2.5: 1$ & $1.5: 1$ & $1.07: 1$ & $2.3: 1$ & $2.23: 1$ & & $1.4: 1$ \\
\hline 2 & Antecedent infection(\%) & 47.5 & 55 & 89.7 & 50 & 65.47 & & 63.8 \\
\hline \multirow[t]{7}{*}{3} & Clinical features (\%) & & & & & & & \\
\hline & (a)Limb weakness & 98 & 100 & 99.8 & 100 & 100 & & 97.2 \\
\hline & (b)Sensory dysfunction & 70 & 32.5 & 37.82 & 25 & 58.9 & & 80.5 \\
\hline & (c)Autonomic dysfunction & 27 & none & - & 20 & 35.25 & & 36.1 \\
\hline & (d)Facial palsy & 45.9 & & 34.39 & & - & & 61.1 \\
\hline & (e)Bulbar weakness & 49.2 & & & & 51.08 & & 30.5 \\
\hline & (f) respiratory distress & & & 16.98 & 35 & - & & 27.7 \\
\hline 4 & $\begin{array}{c}\text { Albumino-cytological dis- } \\
\text { sociation (\%) }\end{array}$ & 80 & 65.3 & & & 38.85 & & 81.8 \\
\hline \multirow[t]{5}{*}{5} & $\begin{array}{c}\text { Electrodiagnostic categoriza- } \\
\text { tion(\%) }\end{array}$ & & & & & & & \\
\hline & (a)AIDP & 60.6 & 100 & - & 22.2 & 89.2 & 86.3 & 34.2 \\
\hline & (b)AMAN & 32.8 & & - & 38.9 & & 7.8 & 25.7 \\
\hline & (c) AMSAN & 5 & & - & 22.2 & - & 5.9 & 25.7 \\
\hline & (d)unclassified /mixed & & & & 16.7 & - & & 11.4 \\
\hline \multirow[t]{3}{*}{6} & Treatment & & & & & & & \\
\hline & (a)recipients of IVIG (n) & 42 & 14 & 51.35 & 14 & 139 & & 32 \\
\hline & $\begin{array}{c}\text { (b)recipients of plasmapha- } \\
\text { resis (n) }\end{array}$ & - & 4 & 48.64 & 1 & & & 1 \\
\hline \multirow[t]{3}{*}{7} & Outcome (\%) & & & & & & & \\
\hline & (a) complete recovery & $\begin{array}{c}75 \\
\text { (3months) }\end{array}$ & 75 & & 70 & & $\begin{array}{c}22.4 \\
\text { (3months) }\end{array}$ & $\begin{array}{c}97.2 \\
\text { (12months) }\end{array}$ \\
\hline & (b)incomplete recovery & 25 & 5 & - & 15 & & 57.1 & 2.77 \\
\hline
\end{tabular}

\section{Discussion}

The study gathered information from 36 GBS patients who were $>18$ years of age, admitted in the Neurology department. The study was an attempt to identify the clinical and epidemiological profile of GBS in adults and to compare with previous clinical studies. ${ }^{10-15}$ (Table 5). Most of the studies were conducted either in children or both adults and children.

In this study, $22(61.1 \%)$ were, $<40$ years and $14(38.8 \%)$ were aged $>40$ years. The mean age was 35 years. Sex ratio showed a slight male preponderance in most of the studies. ${ }^{10-13}$ In the present study also, this trend was observed with males constituting 21 (58.3\%) of the GBS cases. Rainy (June - September) predominance 14 (38.8\%) was noted in our study followed by winter (December-February) 11 (30.5\%), even though it was considered that GBS is sporadic without seasonal preference. ${ }^{16,17}$ In many studies patients admitted with predisposing or associated infection constituted $40-70 \%$ of patients. ${ }^{17-19}$ In our study, $23(63.8 \%)$ of patients had antecedent infection. Respiratory infection was present in $33 \%$ followed by gastrointestinal infection (22\%). Our findings are in accordance with the study done by Sarkar Uk et al. ${ }^{14}$

In present study GBS subtype distribution as per electro diagnostic studies, majority $(\mathrm{n}=12)(34.2 \%)$ had AIDP, followed by 9 (25.71\%) AMAN and 9 (25.71\%) AMSAN, and mixed in 4 (11.4\%). Our study supports the previous study. ${ }^{10,11,15}$ Overall preponderance (51.2\%) was noted in axonal forms (AMAN+ AMSAN) of GBS. Tekqul $\mathrm{H}$ et al. ${ }^{20}$ reported similar findings in children. We found that on comparing demyelinating (AIDP) and axonal (AMAN+AMSAN) forms of GBS, mean age was 
Sandhya et.al.:Guillain-Barré syndrome: Clinical profile and Consensus to revise Hughes grade 5

46 years in demyelinating and 35 years in axonal variant of GBS. Females $7(58.3 \%)$ were affected predominantly in demyelinating form and males $13(72.2 \%)$ in axonal form of GBS. CSF protein levels were increased in 27 (81.8\%). Similar finding were reported by Bhargava et al. ${ }^{10}$ Mean CSF protein was $80.27 \mathrm{mg} / \mathrm{dl}$ and is comparable to studies by Chio et al. ${ }^{21}$ and Corston et al. ${ }^{22}$

Mortality in GBS is associated with respiratory failure requiring mechanical ventilation that prolongs hospital stay. To detect early respiratory failure, all cases with Hughes grade 4 and those with MRC sum score suggestive of moderate (11-30) and severe (0-10) motor deficit were assessed intensively for early respiratory failure. Battery of tests included were baseline measurement of peripheral saturation (Sao2), single breath count (SBC), peak expiratory flow meter and dysphagia tests. Those with $\mathrm{SBC}<15$, Sao 2 of $<95 \%$ and positive dysphagia tests were given oxygen inhalation through nasal cannula, Ryles tube insertion to prevent aspiration pneumonia and early IVIG administration. We modified Hughes grade 5 into two parts, Grade 5A were those who were in respiratory failure, not requiring ventilator or those who can be managed with intensive care (oxygen supplements, ryles tube insertion, management of aspiration pneumonia and early IVIG), other group included those who required mechanical ventilator (cannot be managed conservatively). All our cases 10 (27.7\%) who were in Hughes grade 5A were started with IVIG without delay. None of our cases required mechanical ventilation. Plasmapheresis was not considered in most cases due to time constraints in arranging fresh frozen plasma, shifting patients and delay in availability of bed in dialysis unit, requirement of repeated assessment of bleeding parameters and electrolytes, and risk of hypo tension and infection.

In present study there was a significant association ( $\mathrm{P}$ value- 0.0035$)$ with low MRC sum score (0-10) at nadir and respiratory failure. Low MRC sum score is an independent risk factor for development of respiratory failure and need for mechanical ventilation. Our findings are in accordance with the study done by Wu X et al. ${ }^{23}$ Outcome of patients following IVIG in $32(88.8 \%)$ and plasmapheresis in $1(2.7 \%)$ in present study showed complete recovery in $33(91.6 . \%)$ at 6 months. This is comparable to previous studies. ${ }^{10,11,13,20}$ Early arrival $(<1$ week) to hospital, initiation of intravenous Immunoglobulin and intensive care helped to achieve complete recovery in our study. Axonal form of GBS recovered more slowly than those with demyelinating form but outcome at 12 months appear to be equally favorable in two groups.

\section{CONCLUSION}

Males were predominantly affected. Motor weakness was the most common presenting illness. Female preponderance was observed in demyelinating form and male preponderance in axonal form of GBS. AIDP patients were older, while axonal form were younger. Seasonal occurrence predominantly in rainy season was noted. Axonal (AMAN+ AMSAN) form dominated than demyelinating form (AIDP). Peak flow test, peripheral saturation, single breath count, and bulbar weakness may be a predictor of respiratory failure. There was a significant association of Low MRC sum score with respiratory failure. Early diagnosis of respiratory failure and prompt intervention improves patient outcome. Further large sample studies are required to assess respiratory failure and subdivision of Hughes grade 5.

\section{ACKNOWLEDGEMENT}

Dr Balraj Bhandar sir,Medical Superintendent of ESIC SSH Sanath Nagar,Hyderabad,Sadashiv brother,and Rajendra prasad (Social worker).

\section{REFERENCES}

1. Alter M. The epidemiology of Guillain-Barré syndrome. Ann Neurol. 1990;27(S1):S7-12 http://dx.doi.org/10.1002/ana.410270704; PMid:2194431.
2. Koningsveld RV, Doorn VPA, Schmitz PI, Ang CW, Van Der Meché FG. Mild forms of Guillain-Barré syndrome in an epidemiologic survey in The Netherlands. Neurology. 2000;54(3):620-5. http://dx.doi.org/10.1212/WNL.54.3.620; PMid:10680793.

3. Ram S. India's contribution on "Guillain-Barre syndrome": Mapping of 40 years research. Neurology India 2013,1;61(4):375.

4. Sejvar JJ, Baughman AL, Wise M, Morgan OW. Population incidence of GuillainBarré syndrome: a systematic review and meta-analysis. Neuroepidemiology. 2011;36(2):123-33 http://dx.doi.org/10.1159/000324710; PMid:21422765.

5. Orlikowski D, Prigent H, Sharshar T, Lofaso F, Raphael JC. Respiratory dysfunction in Guillain-Barré Syndrome.Neurocrit Care. 2004;1(4):415-22. http://dx.doi. org/10.1385/NCC:1:4:415

6. Asbury AK, Comblath DR. Assessment of current diagnostic criteria for GuillainBarre syndrome. Ann Neurol. 1990;27(S1):S21-4. http://dx.doi.org/10.1002/ ana.410270707; PMid:2194422.

7. Kleyweg RP, Van Der Meché FG, Schmitz PI. Interobserver agreement in the assessment of muscle strength and functional abilities in Guillain-Barré syndrome. Muscle Nerve. 1991;14(11):1103-9. http://dx.doi.org/10.1002/ mus.880141111; PMid:1745285.

8. Hughes RA, Newsom-Davis JM, Perkin GD, Pierce JM. Controlled trial of prednisolone in acute polyneuropathy. Lancet. 1978;312(8093):750-3. http://dx.doi. org/10.1016/S0140-6736(78)92644-2

9. Hadden RD, Cornblath DR, Hughes RA, Zielasek J, Hartung HP, Toyka KV, Swan AV. Electrophysiological classification of Guillain-Barré syndrome: clinical associations and outcome. Plasma Exchange/Sandoglobulin Guillain-Barré Syndrome Trial Group. Ann Neurol. 1998 Nov;44(5):780-8. http://dx.doi.org/10.1002/ ana.410440512; PMid:9818934.

10. Bhargava A, Banakar BF, Pujar GS, Khichar S.A study of Guillain-Barré syndrome with reference to cranial neuropathy and its prognostic implication. J Neurosci Rural Pract. 2014 Nov;5(Suppl 1):S43-7. http://dx.doi. org/10.4103/0976-3147.145200; PMid:25540538 PMCid:PMC4271381.

11. Dhadke SV, Dhadke VN, Bangar SS, Korade MB.Clinical profile of Guillain Barre syndrome.J Assoc Physicians India. 2013 Mar;61(3):168-72; PMid:24475678.

12. Sudulagunta SR, Sodalagunta MB, Sepehrar M, Khorram H, Bangalore Raja SK, Kothandapani S et al. Guillain-Barré syndrome: clinical profile and management. Ger Med Sci. 2015 Sep 21;13:16.

13. Maneesh Kumar, Shrikiran Aroor, Suneel Mundkur, and Sandeep Kumar. Guillain-Barré Syndrome: A Clinical Study of Twenty Children .J Clin Diagn Res. 2015;9(1):SC09-12. http://dx.doi.org/10.7860/jcdr/2015/8344.5491.

14. Sarkar UK, Menon L, Sarbapalli D, et al. Spectrum of Guillain-Barré syndrome in tertiary care hospital at Kolkata. J Nat Sci Biol Med. 2011;2(2):211-5. http:// dx.doi.org/10.4103/0976-9668.92320; PMid:22346239 PMCid:PMC3276017.

15. Kalita J, Misra UK, Das M. Neurophysiological criteria in the diagnosis of different clinical types of Guillain-Barre syndrome.J Neurol Neurosurg Psychiatry. 2008 Mar;79(3):289-93. Epub 2007 Jul 5. http://dx.doi.org/10.1136/jnnp.2007.118000 PMid:17615164.

16. Van Doorn PA, Ruts $L$, Jacobs BC. Clinical features, pathogenesis, and treatment of Guillain-Barré syndrome. Lancet Neurol. 2008 Oct;7(10):939-50. http://dx.doi. org/10.1016/S1474-4422(08)70215-1.

17. A prospective study on the incidence and prognosis of Guillain-Barré syndrome in Emilia-Romagna region, Italy (1992-1993). Emilia-Romagna Study Group on Clinical and Epidemiological Problems in Neurology. Neurology. 1997 Jan;48(1):214-21. http://dx.doi.org/10.1212/WNL.48.1.214; PMid:9008520.

18. McGrogan A, Madle GC, Seaman HE, de Vries CS. The epidemiology of Guillain-Barré syndrome worldwide. A systematic literature review. Neuroepidemiology. 2009;32(2):150-63. http://dx.doi.org/10.1159/000184748; PMid:19088488.

19. Lyu RK, Tang LM, Cheng SY, Hsu WC, Chen ST. Guillain-Barré syndrome in Taiwan: a clinical study of 167 patients. J Neurol Neurosurg Psychiatr. 1997;63(4):494-500. http://dx.doi.org/10.1136/jnnp.63.4.494; PMid:9343130 PMCid:PMC2169759

20. Tekgul H, Serdaroglu G, Tutuncuoglu S.Outcome of axonal and demyelinating forms of Guillain-Barré syndrome in children. Pediatr Neurol. 2003 Apr;28(4):295-9. http://dx.doi.org/10.1016/S0887-8994(02)00626-4.

21. Chiò A, Cocito D, Leone M, Giordana MT, Mora G, Mutani R. Guillain-Barré syndrome: a prospective, population-based incidence and outcome survey. Neurology. 2003 Apr;60(7):1146-50. http://dx.doi.org/10.1212/01. WNL.0000055091.96905.D0; PMid:12682322.

22. Corston RN, McGale EH, Stonier C, Aber GM, Hutchinson EC. Abnormalities of cerebrospinal fluid amino acids in patients with the Guillain-Barré syndrome. J Neurol Neurosurg Psychiatr. 1981 Jan;44(1):86-9. http://dx.doi.org/10.1136/ jnnp.44.1.86; PMid:7205311 PMCid:PMC490825.

23. Wu X, Li C, Zhang B, Shen D, Li T, Liu K, et al. Predictors for mechanical ventilation and short-term prognosis in patients with Guillain-Barré syndrome. Crit Care. 2015 Sep 2;19(1):310. http://dx.doi.org/10.1186/s13054-015-1037-z; PMid:26330143 PMCid:PMC4557605. 
Cite this article: Manorenj S, Inturi S, Jyotsna B, Arelli D, Reddy OB, Pancheti N. Guillain-Barré syndrome: Clinical profile and Consensus to revise Hughes grade 5. Int J Med. Public Health. 2016;6(4):193-9. 